\title{
SOME ASPECTS OF MEDICINE IN THE GREEK BRONZE AGE*
}

by

\author{
C. P. W. WARREN
}

\section{INTRODUCTION}

Civilization rose to two great heights in ancient Greece, namely in the Bronze age and in the later Classical period. In the latter medicine advanced considerably and culminated in the work of Hippocrates. Knowledge of medicine in the Greek Bronze age depended on the study of Homer until this century, when work in the fields of archaeology and philology provided more facts. This work has shown that this early Greek medicine had much in common with that of its contemporary Near Eastern civilizations. It does not give any indication of the later developments in Greece which were to take medicine to a much higher level than that practised in Egypt and Mesopotamia.

$\begin{aligned} 5,000 \text { B.c. } & \text { Neolithic. } \\ 2,800 \text { B.c. } & \text { The Beginning of the Greek Bronze Age. } \\ 1600 \text { B.C. } & \text { Linear A. } \\ 1450 \text { B.C. } & \text { Linear B. } \\ 1400 \text { B.C. } & \text { Destruction of Knossos. } \\ 1230 \text { B.C. } & \text { Sack of Troy. } \\ 1200 \text { B.C. } & \text { Sack of Pylos. } \\ 1100 \text { B.C. } & \text { Sack of Mycenae. End of Bronze Age. } \\ 730 \text { B.C. } & \text { Homeric poems written. }\end{aligned}$

The Greek Bronze age lasted from 2,800 B.C. to 1,100 B.C., when it was destroyed by the iron-using Dorians (Matz, 1962). Little is known of Greece during the ensuing 'dark age' until the beginning of the Classical period. The Bronze age in Greece is usually subdivided into the Minoan civilization of Crete and the Mycenean of the mainland. The Minoan is remembered in the legends of the Minotaur, Ariadne and Daedalus. The Mycenean is the basis of the Homeric epics, the Iliad and the Odyssey.

The Minoans were a sea power living in unfortified palaces. Their culture was at its height from 2,000 B.C. until their sudden inexplicable destruction in 1,400 B.C. Their main site was at Knossos, with smaller sites at Phaistos, Mallia and Gournia. Archaeological finds show that the Minoans reached a high degree of artistic skill and their public works and records leave evidence of an organized government (Hutchinson, 1962).

The Myceneans lived on the mainland in heavily-fortified castles. Their art was on the whole cruder than that found in Crete, but like the Minoans they had a bureaucracy. Their main sites were at Pylos and Mycenae, which were destroyed in 1,200 B.C. and 1,100 B.C. respectively (Taylour, 1965).

*Maccabaean Prize Essay, Faculty of the History of Medicine and Pharmacy, 1968. 


\section{Some Aspects of Medicine in the Greek Bronze Age}

Both the Minoans and Myceneans came from Asia Minor during the Stone age. At the height of their power they traded with the Egyptians and had colonies in Cyprus and Sicily. They were the first European people to write, but their original script, Linear A, introduced in 1,600 B.C., is still untranslated. In 1,450 B.C. it was replaced by Linear B, which Ventris (1953) has shown to be Greek. The Minoans are usually considered to have been superior to the Myceneans. After the destruction of their cities, the Minoans may have moved to the mainland and offered their skills to the Myceneans; similarly, the Greeks were later to go to Italy during the Roman Empire. Most historians, including Sir Arthur Evans (1921), think Crete was devastated by a natural disaster; Marinatos (1939) suggested it was the result of the eruption of the volcanic island Thira. Recently, Palmer (Palmer and Boardman, 1963) has disputed the dating of this period and has suggested the Myceneans destroyed the Minoans, and that the former were responsible for the fine remains found in Crete. At present the sequence of events of this period is unclear and, until further evidence has been obtained, it is easier to keep to the original scheme proposed by Evans.

Study of the Greek Bronze age developed in three stages. Each stage evolved from the previous one and each provided a new supply of facts for the historian. The first stage was the study of the legends of Homer. The second was the work of the archaeologists. This confirmed many of the conclusions drawn from Homer, besides providing more material. Among the archaeological finds were the Linear B tablets, whose recent translation produced the third source of knowledge. The same three steps are applicable to the history of medicine in that period.

\section{HOMERIC MEDICINE}

Until the end of the nineteenth century, the only source of information on the history of the Greek Bronze age was the poetry of Homer. The Iliad and Odyssey were based on the Mycenean sack of Troy in 1,250 B.C. The legends of the war were handed down by successive ballad singers until Homer wrote them down in 730 B.C. (Webster, 1958). The poet brought the details up to date so that the stories would sound familiar to contemporary audiences. A similar process is found in the legends of King Arthur, whom Malory put in a medieval setting in Morte d'Arthur.

It is still worth examining the medical passages of Homer, for the poems are the oldest Greek literature preserved. Many articles have been written on Homer's medicine and Sigerist (1961) lists twenty-four main ones. The earliest was by Galen, in a lost treatise recorded by Alexander of Tralles in A.D. 600 (Withington, 1894). Frohlich (1876), who published several articles on Homer, even came to the conclusion that Homer was a surgeon. The opinions formed on the medical material of the poems can now be reviewed in the light of modern knowledge.

Health and physical fitness were valued, while the association of physical defects with an unpleasant character was suggested by the poet-'the insolent and abusive Thersites was the ugliest man in the Greek army' (Iliad II, 216). Cleanliness was important and bathing played a part in their daily life and rituals.

Disease came from the gods, as did many of the vicissitudes of life. The plague at the beginning of the Iliad was a punishment from Apollo; animals as well as men 


\section{P. W. Warren}

died. The practice of burning the dead, although sensible as a measure against infection, was the normal funeral custom of that time. The god was appeased, the camp purified, and sacrifices made before the pestilence stopped. It is useless to speculate on the nature of the disease, but it seemed that physicians were not consulted.

The anatomical knowledge shown by Homer was considered to be extensive by some authors, and was one reason why he was thought to be a surgeon. Daremberg (1865) wrote that Homer's anatomy was hardly inferior to that of Hippocrates. Korner (1922) concluded that dissection was probably performed in Homer's day, but Dunbar (1880) pointed out that this was not known to have occurred until five hundred years later under Ptolemy Soter in Egypt. Anatomy is very important in medicine, but it also plays a part in other arts. Nearly two thousand years after Homer, Leonardo da Vinci wrote-'The painter, in order to fashion the limbs correctly in the positions and actions which they represent in the nude, must know the anatomy of the sinews, bones, muscles and tendons' (McCurdy, 1910). The artist is not allowed poetic licence in his work. One cannot say that Homer was a surgeon because he had a knowledge of anatomy. A similar high standard of anatomical detail is seen in the ivory statuette of the acrobat in the Heirakleion museum. The acrobat is vaulting, probably over a bull, and, although damaged, the proportions of the limbs and detail of the left forearm are anatomically correct. The wounds and surgery described by Homer have been analysed too often, for it should be remembered that they are recorded by a poet and not a doctor. Daremberg (1865) even counted the wounds in the Iliad. There were one hundred and forty-one in all and Hollander (1916) estimated that three-quarters were fatal. The descriptions of the wounds were vivid, showing a knowledge of anatomy and vital parts, but no more so than would be obtained by an observant soldier or hunter. Webster (1958) has pointed out that Homer described battle tactics and weapons of different periods in the Iliad. The Heroes wore both early and late Mycenean armour and used iron weapons. The latter, with their superior cutting edge to bronze, would have given different wounds to those experienced by the soldiers of the Trojan war.

The wounds were treated by removal of the weapon, followed by cleansing and binding of the part. Soothing ointments were often applied: 'Patroclus borrowed a sharp knife, knelt down, extracted the arrow, washed the wound in warm water; then, taking from his pouch a bitter root which had both analgesic and styptic properties crumbled it over the flesh'. (Iliad XI, 846).

The drugs used in the Iliad and Odyssey are not named. Schmeideberg (1918) guessed that onions were applied to the wounds. Dunbar (1880) suggested that rose root or geranium were more likely. Internal medicines were not used for the wounded. Odysseus did use an oral antidote to Circe's magic - it had a black root and milkwhite flower' (Odyssey X, 304). By tradition this was garlic. Helen used a drug which 'robs grief and anger of their sting and banishes painful memories', (Odyssey IV, 221). Dunbar thought this was opium or hashish. In Egypt at this time spells and magic played a large part in treatment. Spells are not mentioned in the Iliad, but in the Odyssey when Odysseus was wounded by a boar the bleeding was staunched by a spell.

The heroes of the Homeric age were trained in first aid. The sons of Aesclepius, 


\section{Some Aspects of Medicine in the Greek Bronze Age}

Machaon and Podalirius, were particularly respected for the art of healing. Doctors remember the oft-quoted lines-'We can ill afford to lose a comrade so skilled at extracting arrows and healing wounds: one surgeon is worth several spearmen'. (Iliad XI, 514).

Women nursed the wounded-'Hecamede has warmed a cauldronful of water and washed the clotted blood from your wound', (Iliad XIV, 6). They also helped with the drugs - 'Fair-haired Agamede was the best known herbalist of her day', (Iliad XI, 739).

The poems were thought to be fictitious by many scholars of the nineteenth century. In 1871 and 1874 Schliemann, being self taught, took them literally and excavated Troy and Mycenae at the places described by the poet. This stimulated the start of systematic excavation at many sites in Greece. It is of interest to the medical profession that Virchow had time to help Schliemann in his work.

\section{PUBLIC HEALTH IN THE GREEK BRONZE AGE}

The archaeological finds give no idea of medical practice in the Bronze age such as would be gained from the discovery of surgical instruments or pictures of medical treatment and disease. No pathological material comparable to the Egyptian mummies has been found, although tombs at Mycenae contained skeletons with healed fractures and a jaw with burnt-out osteomyelitis (Wace, 1949). They have shown, however, that the Greeks of the Bronze age were aware of the importance of public health. Surveys of disease in modern Greece have shown that diarrhoea, dysentery and typhoid fever, whose control depends on clean water supply and adequate sanitation, are common (Allbaugh, 1953). These diseases were probably as prevalent in ancient times.

In 1899, Sir Arthur Evans began the excavations at Knossos in Crete which were to become his life's work. One of the first things to arouse interest in the Minoan civilization was the discovery of the well-designed drainage system in the palace. Schliemann had not fully explored Mycenae in 1874 but later digs there by Wace, and at Pylos by Blegen (1954) showed the Myceneans also incorporated drains in their palaces. Sir Arthur was so impressed by the remains at Knossos that he wrote'the palace had a system of drainage superior to that of any ancient civilization, superior indeed to that of any mediaeval city', (Evans, 1921). Captain Clarke (1903), who was medical adviser to the British administration of Crete, also wrote on the sanitation of the Minoan palace at Knossos. He was able to appreciate how far the hygiene of Crete in 1903 had fallen from the standards of the Minoans.

\section{THE DRAINAGE SYSTEMS}

The palace of Knossos was a collection of flat-roofed buildings situated on the west side of the valley of the river Karaitos. The palace was built around a large central court, and the buildings were mainly on its west and east sides. The rooms on the east side, which sloped down to the river, made up the domestic quarters which rose to a height of two or three storeys with the lower rooms lit by light wells. It was under the domestic quarters that the drainage system was found.

The drainage system removed rainwater from the roofs and courts. Gutters from 


\section{P. W. Warren}

the courts entered the main drainage conduits directly, while those from the roofs joined them by four large shafts which descended from the upper storeys of the building. Besides removing the rain the shafts ventilated the drainage system and enabled rubbish to be thrown into it from the upper storeys. The shafts were made of stone and lined with cement. The conduit was flat-roofed, made of limestone flags and lined with cement; a metre high and half as wide. The conduit descended from its highest point in two directions, enclosing an oval, re-united, and passed down towards the river. Most of the conduit was built beneath the passageways of the domestic quarters so there was ease of access for maintenance.

In the domestic quarters, there was a suite of rooms provided with a bath, and a lavatory. By tradition, rooms with such offices were thought suitable for the ladies and were thus named the Queen's rooms by the archaeologist. The lavatory is in a room two metres long by one metre wide. At the back of the room the lavatory, an open drain, ran the width of the floor. The side walls of the room were grooved near the back for a wooden seat. The lower end of the back wall projected into the lavatory and below this projection the lavatory joined the main conduit. This projection may have been the attachment for a 'balance flap' to exclude sewer gas. Another idea is that is was shaped thus to hold a basin, curved at the back, and with the shape of a modern 'washout' closet. Below the floor of the room a small drain runs from a hole in the floor of the passageway outside to connect with the lavatory. Rubbish or water could thus be thrown into the drains without entering the room. Another small lavatory, 'the housemaid's', was found on the second floor of the domestic quarters.

Drainage systems and lavatories have been found at the other palaces. At Mallia, which is twenty-two miles east of Knossos and sited on the coastal plain, the palace has been excavated by the French. The palace was centred round a court and the houses of the town built around it. In the Queen's rooms of the palace two drains and a lavatory were found (Demargue, 1953). A house, not part of the palace, had a simple lavatory which drained to the outside (Demargue and Santerre, 1953). Open drains were laid alongside the sides of the streets. Phaistos, the third big centre in Crete, lies on a hill above the fertile but marshy Messara plain. It has been explored by the Italian school of archaeology. In the northern residential quarter there are the remains of a lavatory and drains. The lavatory is in a huge room, 4 metres by $1 \frac{1}{2}$ metres. At the back a raised gypsum slab acted as a seat and left a $13 \times 28 \mathrm{~cm}$. gap over the drain, which ran to the edge of the hill. Near the Queen's room, in the north east, there is a drain angled steeply downwards and which is thought to be part of the lavatory (Banti, 1951). At Agha Triada, near Phaistos, there was an elaborate stonebuilt drainage system. At Sklavokambos, near Knossos, two clay plugs were fitted to the drains to exclude the sewer gas from the house (Graham, 1962).

On the mainland the drainage systems of the Mycenean palaces have not been fully explored. At Mycenae the living quarters were on the summit of the hill and much of the building has fallen over the edge into a ravine. In the north east there was a drain which passed out through the defensive walls (Wace, 1949). This drain was of interesting construction as the roof consists of two stones making an arch, the corbel technique. This was the only form of arch found in Greece and was used only by the Myceneans. At Pylos, Nestor's palace on the west coast of the Peloponnese, 


\section{Some Aspects of Medicine in the Greek Bronze Age}

the extensive drainage system is not yet fully excavated. Rainwater drained from the courts through perforated stone slabs into the conduits, which were made of upright flagstones covered by flagstones. The largest conduits would have enabled a man to stand upright in them. A lavatory has been found near the entrance to the palace (Taylour, 1965).

Houses of the ordinary people have only been excavated at one place. This is at Gournia, a small Minoan town at the east end of Crete. Sanitation was not provided in the houses or streets (Hawes, 1908). Hutchinson (1950) points out that one could not expect such facilities for the common people. He could only comment like the French officer who, criticized for the lack of latrines in his camp, replied not unreasonably - Mais, monsieur, nous avons toute la campagne'. These are still the only facilities for most of the villagers of modern Knossos.

The drainage systems are often said to have had flushing arrangements and probably jars of water were poured down after use. Some authors suggest that they were continuously washed out by a supply of running water. Rainwater certainly entered the system, but this must have only infrequently cleaned it. There is little water available at the sites today and it seems unlikely there was enough in the Bronze age for continual flushing. The main drains were built large enough for manual cleaning, and this, rather than water flushing, was probably used.

The claim that the Minoan sanitation was second to none in the ancient world cannot be substantiated. Evans must have known, for instance, of such Roman works as the Cloaca Maxima. He did not know that the remains of the Near Eastern civilizations, still to be excavated, would have such advanced drainage systems. As an Englishman brought up in Victorian times, Evans would have been very conscious of the importance of sanitation: the Public Health Act had only just been approved by Parliament in 1875. His pleasure in finding a civilization so conscious of public health may have led to his exaggerated claim. The excavations at Tell-el-Amarna by British and German expeditions have revealed a typical Egyptian town of the Bronze age. The better houses had lavatories draining into an open sewer which ran in the street (Ghalioungui and Dawakhly, 1965). As at Gournia the houses of the ordinary people had no such arrangements. In Mesopotamia the large houses were provided with toilets which drained into the street sewers (Sigerist, 1951).

\section{THE WATER SUPPLY}

The water supply of a community is as important as its drainage system for its health. The water supply of the Greek Bronze age palaces is not fully solved, but much can be learnt from the study of the archaeological remains. Greece is a dry country. The rains fall in October and March and most of the rivers are dry during the summer. In the mountains, springs provide the water, whilst elsewhere wells are used today. In the Bronze age, the rainfall was probably heavier due to the greater tree cover of the land (Hutchinson, 1962).

The river at Knossos dries up in the summer, and as the sewage was discharged into it, it was unlikely to have provided drinking water for the palace. Wells have been found in the palace area but they date back to Neolithic times. The nearest spring is across the ravine of the brook Vlychia to the south of the palace. It is close 


\section{P. W. Warren}

to the Caravanserai, which was a guesthouse, on the main road from the south which crossed the Vlychia to the palace by a viaduct. The spring flows all year and is channelled into a chamber adjacent to the Caravanserai. Hutchinson (1950) thinks water from this spring and nearby wells was carried in pipes across the viaduct and up to the palace. Some pipes in the palace run uphill in the right direction but they may have been displaced by an earthquake. The Minoans would have had to know that water will flow uphill to find its own level. This is the only source of water for the palace which has been found.

One other find connected with water supply is a flight of stairs in the north-east bastion of the palace. A gutter descended in gentle curves beside the stairs, so that the water would not splash. The water was then slowed by bends in the gutter and then led into two basins, which enabled any sediment to settle out. Evans (1921) assumed that rainwater was collected by the system and he thought it supplied the palace laundry. It may have been used to collect drinking water, but the gutter was so small that the amount of water provided must have been very little. Its exact purpose is unclear.

Minoan waterpipes (M.M.I.) have been found in the corridor of the Draughtboard at Knossos. They were beneath the floor and laid on a prepared cement bed. Subsidence had destroyed all but a short length. They were like modern pipes in design and made of terracotta. They were $76 \mathrm{cms}$. long, $13 \mathrm{cms}$. in diameter at one end and tapering to $9.5 \mathrm{cms}$. at the other. They fitted together forming a spigot and socket joint; the joint being waterproofed with cement (Clarke, 1903). Similar pipes have been found elsewhere in Crete and examples are to be seen in the Heirakleion museum.

The palace at Phaistos is situated on a hill high above the river Yeropotamos. The river does not dry up in the summer, but it would have involved a great deal of labour to carry water from it up to the palace. The main source of water at Phaistos was the rain and the large open courts were laid so that rainwater would flow across them into gutters, which channelled it into large cisterns. The cisterns were flask shaped with round well heads. If a cistern overflowed the surplus water was carried by conduits under the buildings to other cisterns (Banti, 1951). The palace at Mallia was supplied by wells (Demargue, 1953).

Some of the Mycenean palaces had their water supply safeguarded against siege. Mycenae relied on the spring of Perseia which rises 200 metres from the east end of the citadel. The water was carried through terracotta pipes to a buried cistern outside the walls. This cistern was reached through an underground passage which descended from inside the defensive wall. The lower part of the passage was waterproofed with cement so that it could be filled with water. Mycenae was able to stand siege as long as the connection with the spring was undiscovered (Wace, 1949). The Mycenean acropolis at Athens had a well sunk in a cleft in the cliff on the north side which was reached from above by a stone and wooden staircase. Tiryns, near Mycenae, had a well within its walls. Pylos had no defensive walls and its water supply was outside the palace (Taylour, 1965).

The springs and wells at all these sites give only a very small supply of water today. They would be inadequate for the needs of the communities which the palaces would have housed. Disuse and earthquakes must have reduced them and probably destroyed 


\section{Some Aspects of Medicine in the Greek Bronze Age}

other sources. There is no evidence that the Bronze age Greeks had built aqueducts or other large works to supply water.

In Egypt and Mesopotamia the drinking water had been obtained from the rivers and canals. The latter had laws to prevent their contamination; for instance, urination into the canals was forbidden (Sigerist, 1951). The only code of Greek laws for that period was found at Gortyns on the Messara plain in Crete. Willetts (1955) believes that the code was Minoan in origin and handed down by tradition until inscribed on a wall in the fifth century B.c. Three of the laws dealt with water supply, but for irrigation, not drinking. Another law forbade the accumulation of refuse in the vicinity of houses. At Knossos three large pits, or koulouria, were provided for rubbish.

\section{PERSONAL HYGIENE}

The Greeks of all periods considered personal cleanliness to be of great importance. The people of the Bronze age were no exception to this, according to Homer, and the archaeological findings confirmed this. Clay bathtubs, of modern design, have been found at several sites. The most complete bathroom was discovered at Pylos. The terracotta tub was enclosed by a clay surround covered with plaster. A step was provided for ease of entry and a ledge for a sponge. In the corner of the bathroom were two large water jars. Broken cups were found in the bath and in the jars. The cups were used to pour water over the bather (Bartsocas, 1962). The bathtub at Mycenae is painted red, by tradition the blood of Agamemnon murdered there by Aegisthus (Wace, 1949). At Tiryns only the bathroom floor remains. It was a large monolithic slab tilted to allow waste water to flow into the drain (Schliemann, 1886). Bathtubs have been found at Knossos, Mallia and Phaistos. The Caravanserai at Knossos had a footbath for the traveller. Inside the building the remains of a clay bathtub and the presence of carbonized wood suggests that hot baths may have been available (Pendlebury, 1939).

The individual bathtub was unknown in Egypt. The bathroom at Tell-el-Amarna showed that water was poured over the body as the bather stood on the floor (Ghalioungui and Dawakhly, 1965). In Classical Greece, as in Rome, the communal baths were used. The Babylonians had bathtubs. They washed before meals and would bathe the whole body at special occasions (Sigerist, 1951).

In the Bronze age palaces there are certain rooms named 'lustral areas'. They are small rooms, the floor lower than the adjacent room, with a short flight of steps leading down to them. They were usually situated near the main rooms of the palace, e.g. next to the throne room at Knossos. Evans (1921) thought they were baths and first named them 'lustral areas'. Nilsson (1950) disagreed with this explanation of their purpose because they had no drainage and were made of gypsum. He considered them to be of religious significance and wondered if they had held snakes which took part in Minoan religious customs. Graham (1962) pointed out that not all gypsum is water soluble and thought the lustral areas were used for ceremonial bathing, for bathrooms did not have drains a hundred years ago in England. Washing was probably a form of hospitality. In the Odyssey Penelope orders her servants 'you must wash our visitor's feet and spread a bed for him' and later 'first thing in 


\section{P. W. Warren}

the morning you must give him a bath and rub him down with oil' (Odyssey XIX, 317).

\section{CLOTHING}

In the hot Mediterranean climate little clothing was worn and this should have encouraged personal cleanliness. The women of the Greek Bronze age wore topless dresses and the men a codpiece and belt. Pendlebury (1939) suggests that the belt was worn very tight to accentuate the slim waist of the Minoans. He thought that the thick padded codpiece was probably necessary as a primitive truss, as he believed that an artificially constricted waist was very productive of rupture.

\section{DRUGS IN THE GREEK BRONZE AGE}

The third phase in the study of the Greek Bronze age came with the translation of the written texts of that period. Evans (1895) had discovered many tablets covered with Linear B script at Knossos. The tablets were made of soft clay and usually lasted only a few years but, when the palace was destroyed by fire, the flames baked the tablets and so preserved them for posterity. In 1952 Ventris announced that the Linear B script was Greek and this view is now generally accepted. Most of the tablets have been translated and as Pendlebury (1939) suspected they were palace inventories. They consisted of lists of stores, debts, land tenures and transactions. Linear B tablets have been found on most excavations.

Stubbs (1931) wrote if it were possible to interpret the Minoan texts we should doubtless find matters of medical interest which would throw light on later Greek developments'. This has unfortunately not occurred and nothing comparable to the Egyptian medical papyri, or even the Assyrian medical texts, has been found. But the tablets have revealed words of medical interest. Tablet Eq 146 (Pylos) contains the word i-ja-te which Ventris and Chadwick (1956) translate as physician. The word is in a list of landholdings and not in a medical context. Palmer (1963) disagrees with this translation and thinks i-ja-te is a word for landowner and he is probably correct. In the Odyssey the physician was included among the itinerant workers and so was unlikely to have owned land 'who would take it on himself to press hospitality on a wandering stranger unless he were some worker for the public good, a prophet, a physician, a shipwright' (Odyssey XVII, 382). In tablets Aa 717 and 815 there are lists of people including a-ke-ti-ra, whom Ventris and Chadwick think were nurses; Hippocrates used a similar word for midwives.

The other tablets of medical interest are those which mentioned plants. The plants were named in palace records and were described by dry volume, weight or in dry bunches. The following plant names have been identified on the tablets: celery, coriander, cumin, cyperus grass, fennel, figs, garden grass, ginger grass, iris root, linseed, mint, pennyroyal, rose, safflower, sage and sesame. One plant po-ni-ki-jo was translated as Phoenician spice by Ventris and Chadwick, but Hein (1961) suggested it was the date palm, Phoenix dactylifera. The palm still grows on Crete and was known in the Bronze age, being depicted on the Hagha Triada sarcophagus (1500 B.C.). Garlic and onion have been found during excavations of the palaces. The Knossos fresco of the monkey picking croci showed that saffron was available. Poppies were known and had some significance. A protogeometric statue of a goddess (900 B.C.) 


\section{Some Aspects of Medicine in the Greek Bronze Age}

found at Gazi had poppyheads on her headdress and a gold ring from Mycenae (1300 B.C.) showed a seated woman holding poppies. Sundwell and Myres (Ventris and Chadwick, 1956) thought the linear B symbol $\uparrow$ indicated a poppy, but because of the large quantities involved Chadwick thought it represented wheat.

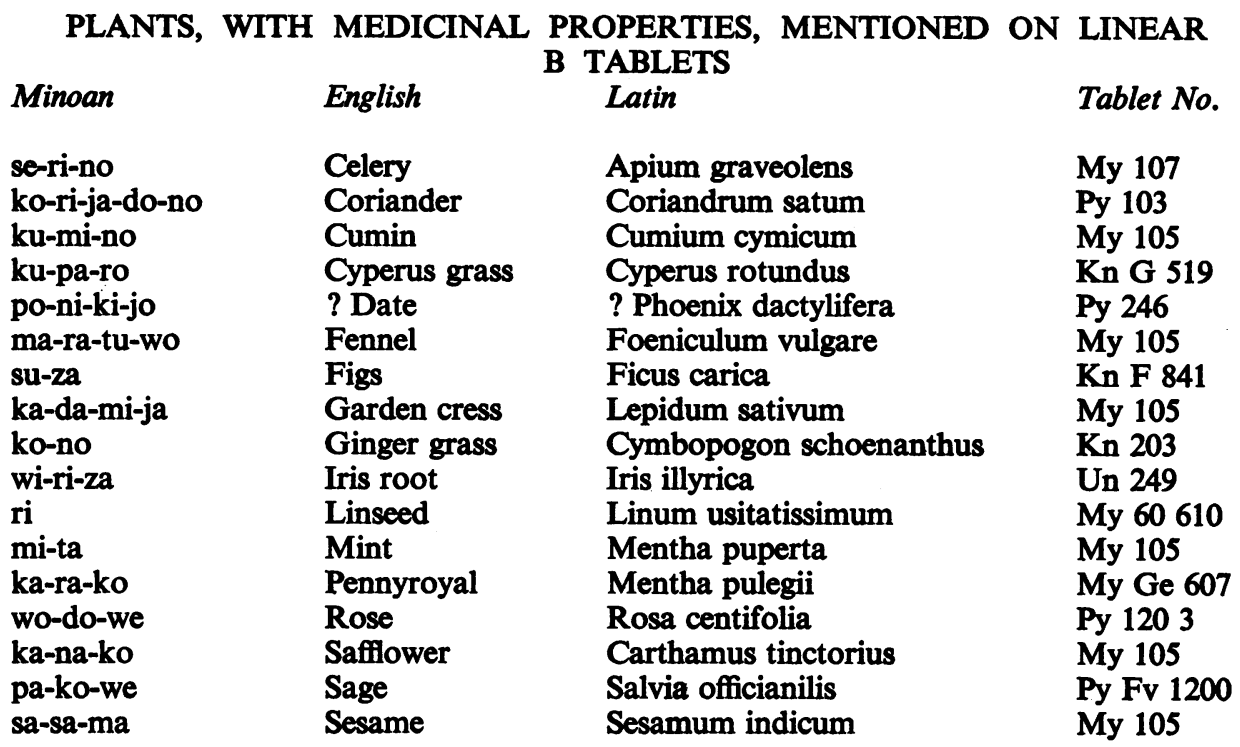

Plants, WITH medicinal PROPERTIES, FOUND ON ARChakOLOGICAL SITES:Garlic, onion, poppy, saffron.

There is no indication on the tablets as to what use these plants were put. Ventris and Chadwick assumed they were foods and spices; they could equally well have been used as drugs. Most of them were included in Fluckiger and Hanbury's Pharmacographia (A.D. 1879) and, although available, rosemary, sage and cumin are not used in modern Greek cooking (Stubbs, 1963). Ten of these plants appear in the Assyrian Herbal (R. Campbell Thomson, 1924), most are mentioned in the Herbal of Dioscorides (first century A.D.). The possible medical uses of these plants can be learnt from the writings of Egyptian medicine and of Dioscorides. There is good evidence of the exchange of medical knowledge between Egypt and Bronze-age Greece and so our greater knowledge of the former can be applied to the latter. Dioscorides, physician to Nero's army, wrote fifteen hundred years after the Bronze age, but his writings reflect on the earlier medicine. Ghalioungui (1968) has found many similarities between Dioscorides and the Egyptian papyri and points out that most of Dioscorides' simples were included in the Edinburgh New Dispensatory of 1786.

The Greeks of Homer's day, and probably those of the Bronze age, had a great respect for Egyptian medicine 'For the fertile soil of Egypt is most rich in herbs, many of which are wholesome in solution, though many are poisonous. And in medical knowledge the Egyptian leaves the rest of the world behind'. (Odyssey IV, 226). Wainwright quotes that oil manufactured in Egypt was used to 'embalm the great 


\section{P. W. Warren}

even as far as the Keftiu [the people of Crete]'. No evidence of embalming of the dead has been found in excavations in Greece.

The exchange of medical knowledge between Egypt and Greece was not all one way. A prescription for constipation in the Eber's medical papyrus was: 'Another to cause purgation: 6 senna [pods] (which are like beans from Crete ... .).

The London medical papyrus was a series of magical spells and prescriptions for burns, bone and eye disease. Part of the papyrus refers to Crete, but it is unintelligible, perhaps a scribe's attempt at Linear B. A translation of the passage is 'Exorcism of the Asiatic sickness in the Cretan language [then follows an untranslated spell]; this spell is uttered over ferment, gas; fluid, urine'. It is thought to deal with eye disease.

Glotz (1953) mentions that the Egyptians obtained ceterach, dittany and daucus from Crete. Thorwald (1962) states that saffron, sage and henna were exported to Egypt from Greece.

There seems to be no rational pattern to the ancient world's treatment of disease and polypharmacy was the rule. There is little point in cataloguing the diseases for which each drug available in the Greek Bronze age could have been used. For instance, Dioscorides recommended celery for stomach ache and belly trouble, to expel worms, to shrink the spleen, to induce menstruation and kill embryos, to incite copulation, and also for poisonous snakes, baldness, boils, sciatica and oedema. But present knowledge of Bronze-age drugs means one can review the nature of Homer's drugs such as Patroclus's healing root, Odysseus's antidote to Circe's magic, and Helen's tranquillizer for Telemachus.

Schmeideberg (1918) thought Patroclus used an onion and Sigerist (1961) accepted this because of the onion's known antiseptic properties. Onions have been found in Bronze-age sites. Dioscorides recommended onion mixed with honey for dog bites but did not mention other wounds. Homer described how Hecamede gave Nestor and Machaon 'a restorative drink of boiled onion juice, pale yellow honey and the flour of pearl barley' (Iliad XI, 624). They were not wounded but weary. Dioscorides stated that the onion made one lethargic. Today the people of the Cyclades use raw onions to sober drunkards; they are rubbed on the testicles.

Dioscorides reckoned cumin, pennyroyal and sage staunched haemorrhage, while the seeds of the iris healed wounds and fractures. All four are named on Linear B tablets but Patroclus used a root. Gentian would have best fitted Homer's description for Dioscorides recorded its warming and healing properties and the root would have been bitter. There is no evidence of its being known in the Bronze age. Dittany was a renowned Cretan herb in Classical Greek medicine and was exported to Egypt. It had the unique property of casting out the weapon from a wound and so Cretan goats would eat it as protection against hunters. Dioscorides only mentioned iron weapons and perhaps it did not work for bronze. Dunbar's suggestion that Patroclus used rose or geranium root cannot be substantiated by Dioscorides as they were not included in his herbal.

By tradition garlic was used by Odysseus against Circe's magic and it has been found during excavations. Dioscorides advised garlic for worms, lice, nits, dog bites, baldness, toothache, ulcers and oedema but did not include the hazard of being transformed into swine. 


\section{Some Aspects of Medicine in the Greek Bronze Age}

Helen was thought to have given Telemachus opium. Pournapolos (1957) thought the goddess with the poppyheads from Gazi was evidence of the Minoan use of opium. In Egypt the poppy was often painted in frescoes but all the poppies found in excavations were species other than papaver somniferis and Georgiades (1917) concluded that opium was not known to the Egyptians. Dioscorides must have known opium for he prescribed poppy for cough, diarrhoea and sleep. If Egyptian medicine did not use opium it was unlikely that Bronze-age Greece used it.

\section{RELIGION AND MEDICINE}

Religion has always played a part in medical practice. There is no trace of Aesclepius in the archaeological remains or writings of the Greek Bronze age, although his sons fought at Troy and so appeared in the Iliad. Eileithea, goddess of childbirth, is the only medical deity mentioned on the tablets. In the Odyssey, as on the tablets, she is associated with Amnisos and her cave there has been excavated. It contained a stalagmite, shaped like an omphalos, around which offerings had been left (Ventris \& Chadwick, 1956).

At Petsofas, a hilltop temple (M.M.I.) a number of votive offerings to a god of healing have been found. These clay models represent limbs, breasts, genitalia and perhaps a hemiplegic and paraplegic (Pournapolos, 1957). No other pathology is shown unless the thick legs are oedematous.

The snake played an important part in Minoan religion, but there is no evidence of a medical role for it. The faience statuettes from Knossos (seventeenth century B.C.) of the snake goddesses show two women holding snakes. They may represent a snake-handling sect; a custom found in certain churches of the Southern United States (Sargant, 1959).

\section{CONCLUSIONS}

Greece in the Bronze age was the home of one of the great civilizations of the early world. Its importance increases when it is remembered as the forerunner of one of the greatest cultures in the history of the world. The writing, architecture and art of the Greek Bronze age perished with it. Only its language and the legends of its people were handed on to the classical period.

During the classical period in Greece, medicine developed a long way from that of the preceding centuries. The practice of medicine changes often at all times and the Greeks did not add many significant developments to it. But the principles of medicine, embodied in the Hippocratic writings, were to influence the medical thought of the Western world for many centuries. It was in classical Greece that medicine lost its magic tones and began to develop the empirico-rational basis which it has today.

The wealth of material now available on the Greek Bronze age has made it possible to study the medicine of that period. Medical historians had hoped that this would throw light on the early stages of the development of classical Greek medical thought, but the evidence gives no indication of a connection between the medicine of the two periods. Homer inspired later Greek culture but his works were not used as medical texts. The drainage systems found in the Bronze-age palaces disappeared with the Bronze-age style of architecture. Herodotus (fifth century B.C.) would not have been 


\section{P. W. Warren}

so surprised at the Egyptian indoor lavatories if he had known of the Queen's rooms at Knossos. The Linear B tablets only show that the people collected herbs later used in Greek medicine.

The evidence confirms Garrison's views (1929) that pre-Hippocratic medicine in Greece owed much to Egyptian medicine. Homer's opinion on Egypt, the similar approach to sanitation in the two countries and the writings in the Egyptian papyri are examples of the exchange of ideas between the two countries and it is to Egypt and not to the Greek Bronze age that one must look for the developments of Greek medicine.

It would be encouraging to think that more will be learnt about medicine in the Bronze age. Excavations are continuing and more Linear B tablets will be found. Long texts cannot be expected on the tablets, and papyri, if ever written, would not have survived in Greece's climate. The records of a doctor or a pharmacist would be of great interest and the medical historian must watch carefully for such finds. The most exciting prospect for the future is the discovery of a Minoan town on Thira. It is buried under volcanic ash and well preserved. Marinatos (1967) hopes it will be as important a find as Pompeii.

\section{REFERENCES}

Allbaugh, L. G., Crete, a Case Study of an Undeveloped Area, 1953.

Banti, L., Il Palazzo di Festos, 1951, vol. 2, p. 296.

Bartsocas, C. S., 'A few concepts of hygiene during the Mycenean era', Nosokon Chron., $1962,24,118$.

Bartsocas, C. S., 'Mycenean medicine', Hellin. iatr., 1959, $28,5$.

Blegen, C. W., Excavations at Pylos, 1954, pp. 56-57.

Clarke, T. J. H., 'Prehistoric sanitation in Crete', Brit. med. J., 1903, ii, 597.

Daremberg, C., La Médecine dans Homère, Paris, 1865.

Demargue, P., Mallia-Fouilles executées a Mallia, Paris, 1953.

Demargue, P. and De Santerre, H. G., Mallia Maisons, Paris, 1953, p. 45.

Dunbar, H., 'Homeric medicine', Brit. med. J., 1880, ii, 48.

EVANS, SIR ARTHUR, 'Cretan pictographs and pre-Phoenician scripts', J. Hell. Stud., 1895.

Evans, SIR Arthur, The Palace of Minos, Oxford, 1921-35.

FluCkIGer, F. A. and Hanbury, D., Pharmacographia, London, Macmillan, 1879.

FroHLICH, Die Militar-medizin Homer, Stuttgart, 1879.

Garrison, F. H., An Introduction to the History of Medicine, Philadelphia, 1929, p. 57.

Grorgiades, N., 'Contribution a l'étude de l'opium egyptien', Bull. Inst. Egypt, 1917.

Ghalioungui, P. and Dawakhly, Z. Health and Healing in Ancient Egypt, Cairo, Dar Al-Maveef, 1965, p. 43.

Ghalioungui, P., 'The relation of Pharaonic to Greek and later medicine', Bull. Clev. Med. Lib., 1968, 15, 96.

Glotz, G., The Aegean Civilisation, Paris, 1953, p. 388.

Graham, J. W., The Palaces of Crete, Princeton, 1962.

HAWES, H. BOYD, Gournia, 1908.

HeIN, W. H., 'Die bedeutung der Entzifferung des Linear B fur die Arzneimittelgesichte', Pharm. Ztg., 1961, 106, 1145.

HOLLANDER, 'Ueber die historische Entwicklung künstlicher Gliedmaassen', Berl. klin. Wschr., 1916, 53, 355.

Hutchinson, R. W., 'Prehistoric town planning in Crete,' Town planning Rev., October 1950.

Hutchinson, R. W., Prehistoric Crete, London, Penguin Books, 1962.

KORNER, O., 'Wie enstanden die anatomischen keutnisse in Ilias und Odysee', Münch. med. Wschr., 1922, 1484. 


\section{Some Aspects of Medicine in the Greek Bronze Age}

Marinatos, S., 'The volcanic destruction of Crete', Antiquity, December 1939.

Marinatos, S., Quoted in The Times, 1967.

MATZ, F., Crete and Early Greece, London, Methuen, 1962.

McCuRdy, E., The Notebooks of Leonardo da Vinci, 2 vols., London, 1938.

NANNINI, M. C., 'Considerazione igienico sanitare a Gurnia', Econ. umana., 1962, 13, 3, p. 4.

NIIsson, M., The Minoan-Mycenean Religion, Lund, 1950.

PALMER, L. R., On the Interpretation of Mycenean Greek Texts, Oxford, 1963.

Palmer, L. R. and BoArdman, J., On the Knossos Tablets, Oxford, 1963.

Pendlebury, J. D. S., The Archaeology of Crete, London, Macmillan, 1939.

Pournapolos. G. C., 'Medicine in Crete during the Minoan period', Acad. Med. (Athens), 1957, 22, 57.

SARGant, W., Battle for the Mind, London, Pan, 1959.

SAUnders, J. B. de C. M., The Transitions from Ancient Egypt to Greek Medicine, University of Kansas Press, 1963.

SchlizmanN, H., Mycenae, London, 1878.

SChliemanN, H., Tiryns, Leipzig, 1886.

SCHMEIDEBERG, O., 'Uber die pharmaka in der Ilias und Odysee', Strassburg, 1918.

SigERIST, H., A History of Medicine, Oxford, vol. 1, 1951; vol. 2, 1961.

StubBs, J. M. S., The Home Book of Greek Cookery, London, Faber, 1963.

StuBbs, S. G. B. and Bugh, R. W., Sixty Centuries of Health and Physick, London, Sampson Low, 1931, p. 40.

TAYlour, LoRd William, The Myceneans, London, Thames \& Hudson, 1965.

Thomson, R. CAmpbell, The Assyrian Herbal, London, The Royal Society, 1924.

THORWALD, J., Science and Secrets of Early Medicine, London, Thames \& Hudson, 1962, p. 73.

VENTRIS, M., 'A note on decipherment methods', Antiquity, 1953.

Ventris, M. and ChaDWICK, J., Documents in Mycenean Greek, Cambridge, 1956.

WACE, A. J. B., Mycenae, an Archaeological Guide, Princeton, 1949.

Wainwright, L. A., Ann. Arch. Anthr. Lpool Univ., VI, 79, 2.

WARREN, C. P. W., 'Minoan medicine; first in Europe', Guy's Hosp. Gaz., 1965, 79, 34.

WeBster, T. B. L., From Mycenae to Homer, London, Methuen, 1958, chapter 8.

WilletTs, R. F., Aristocratic Society in Ancient Crete. London, Routledge, Kegan Paul, 1955.

Wrthington, E. T., Medical History from Earliest Times, London, Scientific Press, 1894.

ANCIENT Authors

Dioscorides (1st century A.D.), Greek herbal, trans. by R. T. Gunther, Oxford, 1934.

Herodotus (5th century B.C.), The Histories, II, 35, trans. Aubrey de Selincourt, London, Penguin.

Homer (730 B.c.) The Iliad, trans. R. Graves, London, Cassell, 1959.

The Odyssey, trans. E. V. Rieu, London, Methuen, 1945.

Theophrastus (370 B.C.), Enquiry into Plants, trans. Sir Arthur Har, London, Heinemann, 1916.

Egyptian Papyri

Papyrus Chester Beatty (1200 B.C.), British Museum.

Eber's Medical Papyrus (1200 B.c.), trans. B. Ebbell, Levin and Marksgaard, 1937.

London Medical Papyrus (12th century B.C.), trans. H. von Deines, H. Grapow and W. Westendort, Ubersetzung der Medizinischen Texte, IX, 258, Berlin, 1958. 